Purdue University Purdue e-Pubs

$1-1-1999$

\title{
Global Diversification, Industrial Diversification, and Firm Value
}

David J. Denis

Purdue University

Diane K. Denis

Purdue University

Keven Yost

Purdue University

Follow this and additional works at: http:// docs.lib.purdue.edu/ciberwp

Denis, David J.; Denis, Diane K.; and Yost, Keven, "Global Diversification, Industrial Diversification, and Firm Value" (1999). Purdue CIBER Working Papers. Paper 141.

http://docs.lib.purdue.edu/ciberwp/141

This document has been made available through Purdue e-Pubs, a service of the Purdue University Libraries. Please contact epubs@purdue.edu for additional information. 
Center for International

Pusiness Education and Research

\section{Global Diversification, Industrial}

\section{Diversification and Firm Value}

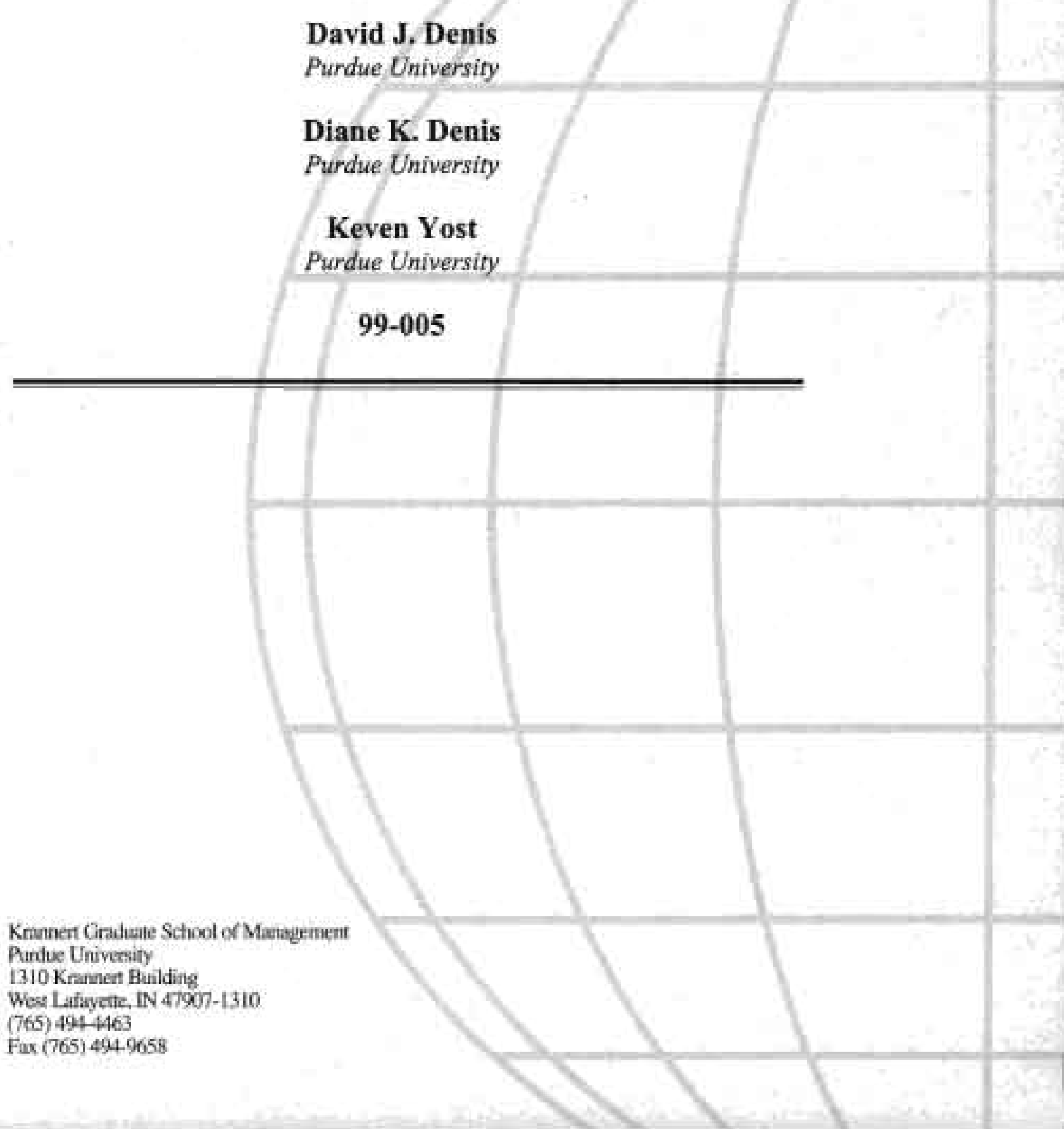




\title{
Global Diversification, Industrial Diversification, and Firm Value'
}

\author{
David J. Denis, Diane K. Denis, and Keven Yost \\ Kranner Graduate School of Management \\ Purdue University
}

West Lafayette, IN 47907-1310

January, 2000

Preliminary and incomplete

Comments weleome

\begin{abstract}
Using a sample of 27,287 firm-years over the period 1984-1993 we document an increasing trend in both the incidence and level of global diversification over time. This trend does not, however, reflect a substitution of global for industrial diversification. Global diversification results in average valuation discounts of the same magnitude as those for industrial diversification. Analysis of the changes in excess value associated with changes in diversification status reveals that increases in global diversification roduce excess value, while reductions in global diversification increase excess value.
\end{abstract}

- This project has been funded in part by a summer reasearch grant from Purdue Universiry's Cenier for International Business and Edacation Research (CIBER). 


\section{Global Diversification, Industrial Diversification and Firm Value}

\section{Introduction}

A considerable fraction of U.S. corporations diversify their operations, either across multiple lines of business (industrial diversification), across different national markets (global diversification), or both. Over the past decade, an extensive academic literature has developed documenting the causes and consequences of industrial diversification. Studies in this literature report that, on average, diversified firms are valued at a discount relative to a portfolio of comparable single-segment firms. This value discount appears to stem, in part, from inefficiemt investment policies in diversified firms. In addition, the evidence indicates a trend towards less industrial diversification since the mid-1980s, and a gain in shareholder value associated with refocusing strategies.' Collectively, these findings suggest that, on average. the costs of industrial diversification outweigh the benefits. Because industrial diversification potentially benefits corponate managers through increased power and prestige, through compensation arrangements, or through personal risk reduction, a plausible interpretation of this evidence is that industrial diversification represents a cost of the agency relationship that exists between managers and shareholders.'

Considerably less attention has been focused on the causes and consequences of global diversification, and virtually none on the relation between the two forms of corporate

\footnotetext{
'For evidence on the valuatioe effects of industrial diversification, see Berger and Ofek (1995), Lang and Stult (1994), and Servaes (1996). Evidence on the investment policies af diversified firms can be found in Denis and Thethadri (1999), Rajan, Servaes and Zingales (1999), Scharfitein (1997) and Shin and Stult (1995). For evidence os the tread towatuh increased componte focus and the valuation consequences of this inereased focus. seo Comment and Jarreli (1995)

'Further apport for this iaterpretution cames from the findings in Deais, Denis, and Sarin (1997) that (0) divernified firms are characterized by lower managerial equity ownerihip and lower equity ownership by ounide blockholden, and (i) decreases in industrial diversification are often precipitated by market desciplinary forces such as corporate control threats.
} 


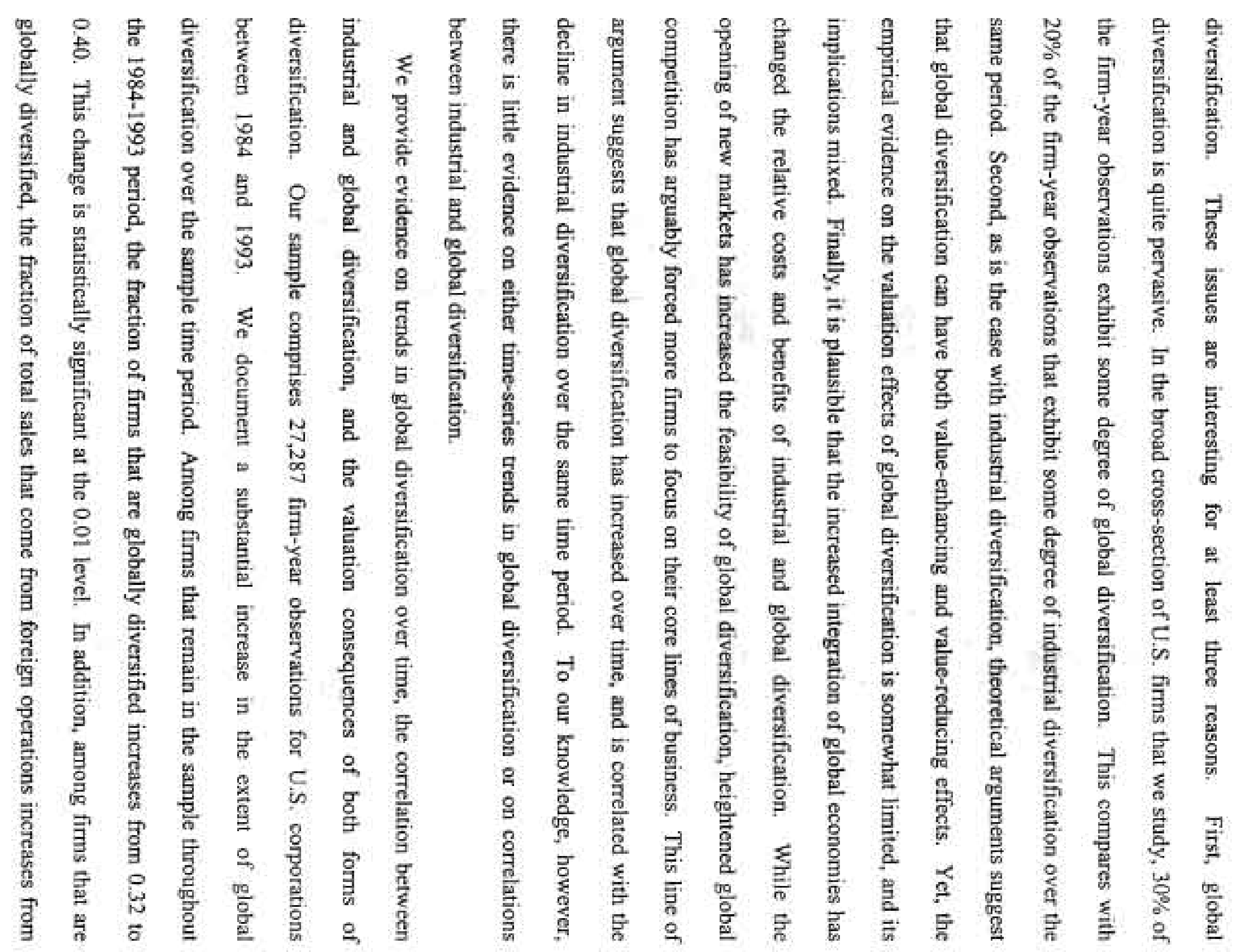




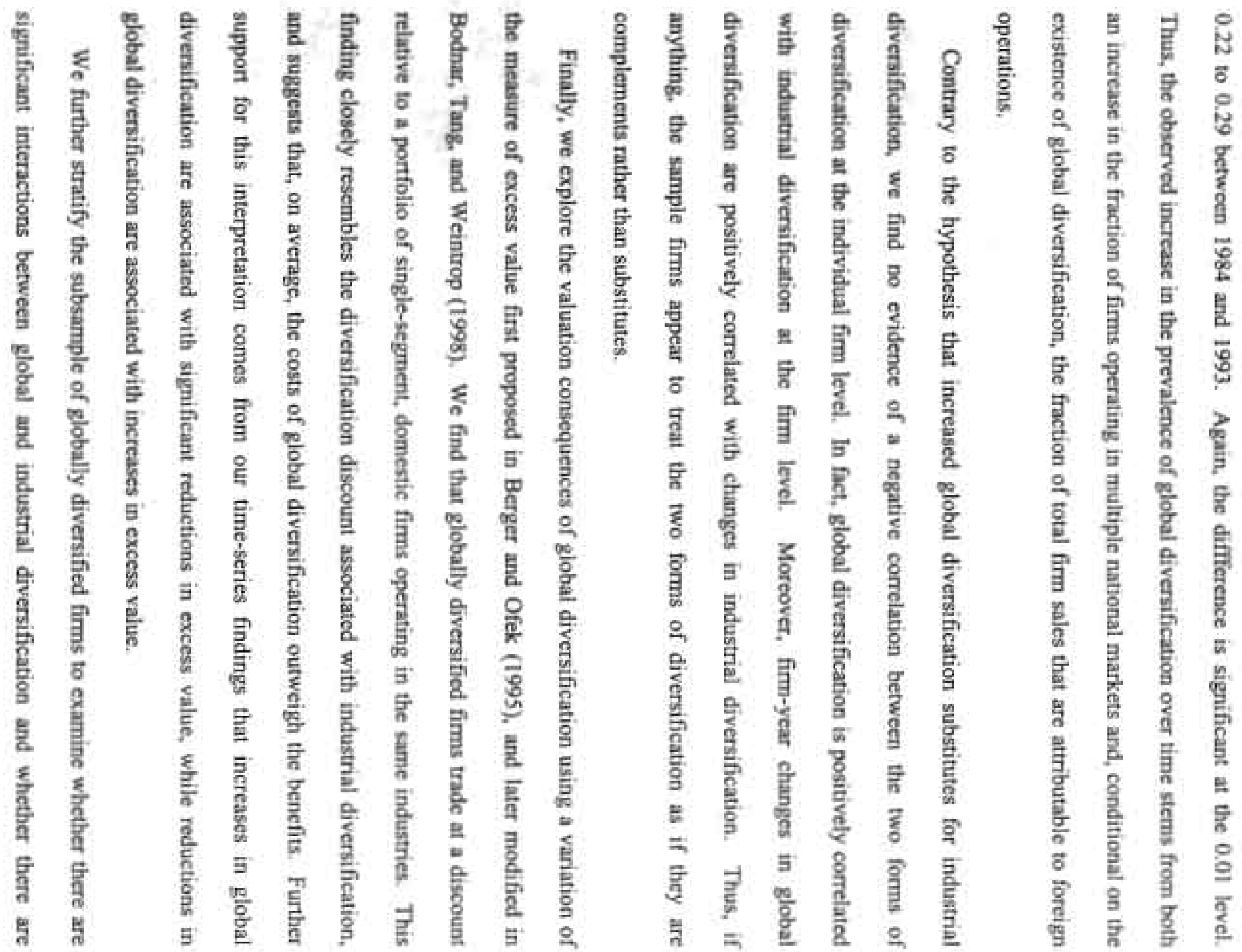


variations in the valuation consequences of this interaction over time. We find that firms that are both globally and industrially diversified do not suffer a diversification discount on average. However, this result is driven by the latter half of the sample period, in which firms that are both globally and industrially diversified are valued at a premium relative to single segnent, domestic firms. Moreover, multivariate analysis reveals that, after controlling for other factors that potentially affect excess value, being globally diversified is associated with a diversification discount that is similar in magnitude to that associated with being industrially diversified. This discount hoids across time periods and whether or not the firm is also industrally diversified. Thus, we conclude that global diversification, like industrial diversification, has a negative valuation effect on the average firm.

The remainder of the paper is organized as follows. Section 2 outlines the theoretical costs and benefits of global diversification and reviews the existing empirical evidence. We also develop hypotheses for the relation between industrial and global diversification. Section 3 describes our sample selection process and measures of diversification, and reports some descriptive statistics. Section 4 presents our primary empirical results. Section 5 concludes.

\section{Theory and prior evidence on global diversification}

Theoretical arguments suggest that global diversification can have both postive and negative effects on firm value. In addition, the relative costs and benefits of global diversification have, in theory, changed over time. In this section, we review the theoretical arguments on these issues and discuss the related empirical evidence. 


\section{Potential costs and benefits}

Previous authors hypothesize that global diversification enhances shareholder value by exploiting firm-specific assets, by increasing operating flexibility, and by satisfying investor preferences for holding globally diversified portfolios.

Morck and Yeung (1998) propose that the value of diversification has its roots in the internalization theory of synergy, proposed initially in Caves (1971). According to this theory. synergistic benefits stem from the existence of valuable information-based assets within the firm. Because these assets have increasing retums to scale, and are difficult to sell, it is optimal for firms possessing information-based assets to internalize the markets for these assets. Global diversification ean be viewed as one mechanism for bringing buyers and sellers of information. based assets together within the same firm. According to this view, therefore, global diversification increases value in the presence of substantial intangible assets, such as superior production skills, marketing skills, and management quality.

Global diversification might also increase value by creating the flexibility within the firm to respond to changes in relative prices, differences in tax codes, and other institutional differences. For example, the multinational firm has the fexibility to shift production to that country in which production costs are lowest, or shift distribution to that country in which market demand is highest. This argument is similar to Stein's (1997) 'winner-picking' model of investment decisions in industrially diversified firms. Similarly, the multinational firm has the ability to lower the firm's overall tax lability by exploiting differences in tax systems across countries, and, assuming some degree of market segmentation, can choose to raise capital in the country in which the costs of doing so are lowest. 
Finally, the benefits of global diversification can arise from investors' diversification preferences. To the extent that corporations can diversify internationally at lower cost than can individuals, investors will be willing to pay a premium for globally diversified firms, ceteris paribus.

Although there are several possible ways in which global diversification can enhance sharchoider wealth, there are equally plausible reasons to believe that global diversificanion will reduce shareholder wealth. A globally diversified organization is more complex than a purely domestic firm. This complexity can lead to high costs of coordinating corporate policies. Myerson (1982) and Harris, Kreibel, and Raviv (1982) discuss costs of information asymmetry between corporate headquarters and divisional managers in multi-segment organizations. In addition, Bodnar, Tang, Weintrop (1998) hypothesize that the monitoring of managerial descision-making can be more difficult in a complex, globally diversified firm.

As is the case with industrial diversification, global diversification can also lead to the inefficient cross-subsidization of less profitable business units. Meyer, Milgrom, and Roberts (1992), Rajan and Zingales (1995), Rajan, Servaes, and Zingales (1999), and Scharfstein and Stein (1997) present models in which divisional managers exert influence to increase the assets under their control. This leads in some cases to less profitable divisions being subsidized by (and at the expense of more profitable divisions.

It is worth noting again that managers may have the incentive to adopt and maintain valuereducing diversification strategies even if doing so reduces shareholder wealth. Managers can benefit from global diversification in at least three ways. First, managing a large, multinational corporation confers much greater power and prestige on the manager [sec, e.g. Jensen (1986) and Stulz (1990)]. Second, levels of managerial compensation tend, on average, to be positively 
correlated with firm size [sce, e.g. Jensen and Murphy (1990)]. Third, to the extent that the cash flows of global segments are imperfectly correlated, global diversification reduces the risk of the manager's relatively undiversified personal portfolio [see, e.g. Amihud and Lev (1981)]. If these private benefits exceed the managers' private costs, the firm may pursue value-reducing global diversification.

\subsection{Trends in diversification over time}

It is possible that the relative costs and benefits of industrial and global diversification have changed over time. Shleifer and Vishny (1991) argue that the relaxation of antitrust enforcement in the early 1980 s allowed firms to focus more on their core line of business, thereby diminishing the value of industrial diversification. In addition, Liebeskind and Opler (1994) suggest that an increased focus on core lines of business may have been necessitated by increases in global competition. At the same time, the increased integration of world markets has made global diversification more feasible. On net, therefore, these factors predict that changes in the global competitive environment have led to an increase in global diversification and a decrease in industrial diversification over time.

An alternative view, however, is that decreases in industrial diversification represent forced reversals of pnor diversification mistakes [see, e.g. Jensen (1993)]. Under this view, the active market for corporate control in the 1980 s and enhanced corporate governace practices have

limited the ability of managers to pursue value-reducing industrial diversification strategies. If diversification decisions are driven by agency cost considerations, the implications of this for the trend in global diversification over time are unclear. If global diversification, like industrial diversification, reduces value, we expect a decrease in global diversification over time. On the 
other hand, if global diversification is either value-increasing or at least less value-feducing than industrial diversification, we expect an increase in global diversification over time.

Managers can achieve many of the same private benefits with global diversification as they can with industrial diversification. To the extent that global diversification has become more feasible over time due to the opening of new international markets, and the private costs of global diversification are lower than for industrial diversification, managers may substitute global diversification for industrial diversification. This argument suggests a trend towards increased global diversification over time and a negative correlation between changes in industrial and global diversification.

\subsection{Prior empirical evidence}

Several prior studies have examined the valuation effects of global diversification and have produced mixed results. Using samples of multinational firms only, Emunza and Senbet (1981, 1984) document a positive relation between their measure of excess firm value and the firm's degree of internationalization. They interpret their findings as evidence that global diversification completes the market for investors who otherwise face barriers to international capital flows. Like Errunza and Senbet (1981, 1984), Morek and Yeung (1991) document a positive relation between firm value and internationalization. However, Morck and Yeung (1991) find that this positive association is present only for those firms with firm-specific intangible assets. Thus, they interpret their findings as support for the view that global diversification enhances firm value because it allows firms to exploit their firm-specific skills on a global level. 
A drawback to the above studies is that they employ relatively small samples of firms from the 1970s. Using larger samples from the 1980s and 1990s, Bodnar, Tang, and Weintrop (1998) find that global diversification is associated with higher firm value, while Christophe (1997), and Christophe and Pfeiffer (1998) find that global diversification reduces firm value

Thus, the evidence on the valuation effects of global diversification is largely inconclusive. In addition, although there is substantial evidence on trends in industrial diversification over time [sec, for example, Comment and Jarrell (1995)], there is, to our knowledge, no comparable evidence on trends in global diversification over time. Finally, the relation between changes in industrial diversification and changes in global diversification is unexplored. In addition to providing further evidence on the valuation effects of global diversification, our study addresses these issues.

\section{Sample selection and diversification measures}

\subsection{Sample selection}

Beginning in 1977, U.S. firms are required to report audited financial information for individual industrial and foreign segments that account for greater than $10 \%$ of consolidated sales, profits, or assets. Compustat reports this information on its Industry Segment and Geographic Segment tapes.' The accounting data available by segment is limited to sales; operating profit; depreciation, depletion, and amortization; capital expenditures; and identifiable assets.

\footnotetext{
'Compustar defines goographic segmenta based upon operations at the country level. Authors of prior research on diversificatson across countries also frequently term such diversificanon to be 'geographic:' However, because 'geographic' diversification could also rugasat diversification actoss regiona of a country, we prefer to tase the term 'global' diversification.
} 
In each year from 1984 through 1993, we identify all firms for which there is data on both the Industry Segment and the Geographic Segment tapes. We eliminate utility and financial firms (SIC codes 4900-4999 and 6000-6999, respectively), and firms incorporated outside of the U.S. We eliminate firm-years in which any industrial segment has sales of less than $\$ 20$ million and firm-years in which the total of either industrial or global segment sales is not within $1 \%$ of total reported firm sales for that year. ${ }^{4}$ This results in a sample of 27,287 firm years, associated with 5,332 firms.

Table 1 presents descriptive statistics on size and diversification measures for the overall sample and for the subsamples that are industrially and globally diversified. The mean (median) firm has assets of $\$ 974$ million ( $\$ 127$ million) and sales of $\$ 985$ million ( $\$ 159$ million). Globally diversified firms are larger than the sample as a whole and industrially diversified firms are larger than globally diversified firms, on average.

We report three measures of industrial diversification in table 1: the reporting of more than one business segment, the average number of business segments, and a sales-based Herfindahl index. In $20 \%$ of the sample firm-years, more than one industrial segment is reported; i.e. the firm is industrially diversified in that year. Of the firm-years that are globally diversified, $33 \%$ are also industrially diversified. The average number of industrial segments is 1.39 overall, 2.91 among industrially diversified firm-years, and 1.68 among globally diversified firm-years. It should be noted that Compustat limits the number of industrial segments to ten; however, there are only ten firm-years in which ten industrial segments are reported. Finally, the average sales-

\footnotetext{
${ }^{4}$ These sales-related requirements are associated with the calculation of the excess value measures that will be utilized in the paper. The requirement that all industrial segments have sales of at least $\$ 20$ million avoids the problem of comparing very small segments to much larger single-segment firms. The requirement that segment sales total within $1 \%$ of total firm sales ensures that all firm sales have been allocated to individual business and global segments. This requirement is common to other diversification studies.
} 
based Herfindahl index is 0.90 overall, 0.52 among industrially diversified firms, and 0.84 among globally diversified firms.

Global segment data provided by Compustat are much less detailed than industrial segment data. The number of giobal segments is limited to four, including the domestic segment, i.e no more than three foreign segments are reported for any fim, regardless of the number of countries in which it operates. Given this limitation, the number of global segments in which a firm operates has limited meaning and we do not report it as a measure of global diversification. In addition, because the database does not specify the individual countries that are included in each segment, we are unable to use number of countries as a measure of global diversification.

Table 1 presents summary statistics for two measures of giobal diversification: the fraction of firms that are globally diversified and the fraction of total sales that comes from foreign operations., We classify a firm as giobally diversified if it reports any sales by foreign subsidiaries. Thirty percent of the sample firm-years are globally diversified; among the subsample of firm-years that are industrially diversified, this rises to $48 \%$. The average firm in the average year derives $8 \%$ of its sales from foreign operations; for industrially diversified firms the corresponding figure is $11 \%$. Among firms that are globally diversified, foreign saies average $26 \%$ of total annual sales."

\footnotetext{
'Export sales by the domestic subsidiary are not treated as foteign sales.

"Compustat reports sales for each of the four global atgments, at well as total foreign saies. However, there ane 741 firm-years for which the global segment that includes the domestic operationa slso includes some foreign operations. Compustat reports total foreign saies for these firms as missing because it cannot isolate the foreign from the domestic sales in that one gegment. We adjust total foreign sales for these firms to equal the sum of sales in the three segments that do not include any domestic operations. By doing so, we apptopriately label these 743 firms as globally diversified. Their foreign sales, however, will be understated by the amount of foreign sales that is included with the domestic segment.
} 


\subsection{Diversification trends}

One purpose of this study is to document trends in diversification among U.S. corporations. In table 2, we document industrial and global diversification measures by year. Panel A presents results for the sample as a whole. The fraction of the sample firms that are industrially diversified declines steadily over the period, from 0.262 in 1984 to $0.161 \%$ in 1993 . Furthermore, the degree of diversification observed among those firms that are industrially diversified also declines over the period. The average industrially diversified firm in 1984 has 3.15 segments, while the average industrially diversified firm in 1993 has only 2.74 segments. The decline is steady and monotonic, with the exception of a small increase in the average number of segments in 1992. The sales-based Herfindahl index increases from 0.49 to 0.54 over the period, again consistent with a decrease in the degree of industrial diversification. For all three industrial diversification measures, the change from 1984 to 1993 is significant at the 0.01 level. These results are consistent with those of Comment and Jarrell (1995), who document increases in industrial focus over the 1978-1989 time period.

The panel A results for the global diversification measures suggest a trend towards increased global diversification, though not a particularly strong one. The fraction of the sample firms that are globally diversified is essentially constant over the period, varying only slightly on either side of $30 \%$, and the change in this fraction from 1984 to 1993 does not differ significantly from zero. Among those firms that are globally diversified, however, the fraction of sales that comes from their foreign operations increases over time, on average, from 0.212 in 1984 to 0.278 in 1993. The change over the whole period is significant at the 0.01 level.

The panel A results could be somewhat misleading. The increasing number of firms indicates a net addition of firms over time. If new firms are less likely to be either industrially or 
globally diversified than those firms already in the sample, there will be a bias towards reduetions in average diversification over time even if individual firms are not altering their diversification status. To examine this issue, we reproduce the panel A results for the subsample of firms that are in the sample both in 1984 and in 1993. We label this the constant composition sample.

The results for this subsample, reported in panel B, indicate that, among firms that are on Compustat in both 1984 and 1993, the fraction of firms that are industrially diversified decines only from 0.291 in 1984 to 0.267 in 1993; this decline does not differ significantly from zero. On the other hand, there is a pronounced and statistically significant (at the 0.01 level) increase in the fraction of firms that are globally diversified in this subsample: from 0.323 to 0.403 . The panel B results with respect to degree of diversification are essentially the same as those in panel A. The degree of industrial diversification declines significantly over the sample period, while the degree of global diversification increases significantly.

\subsection{The relation between global and industrial diversification}

The results of the previous subsection establish that there is a decline in the degree of industrial diversification and an increase in the degree of global diversification over the sample period. As discussed earlier, there are at least two reasons to think that these trends may be related at the firm level. First, the increased feasibility of global diversification may lead firms to sabstitute global for industrial diversification, perhaps because resources limit the ability to pursue both, and/or because global competitiveness is enhanced by greater focus on an industrial

core. Second, if industral and global diversification provide similar private benefits to 
Finally, panel $\mathrm{C}$ of table 3 presents correlations among changes in the base variables between 1984 and 1993 for the subsample of firms that are in the sample in both 1984 and 1993. For the full subsample, the correlations do not differ significantly from 0 , suggesting no relation at all among changes in industrial and global diversification.

Overall, the table 3 results provide no evidence that increases in global diversification over time are due to a substitution of global for industrial diversification by individual firms. In the following section, we examine the valuation effects of global and industrial diversification.

\section{The valuation effects of diversification}

\section{I Excess value}

We measure the valuation effects of diversification using a variation of the excess value measure originally developed by Berger and Ofek (1995) and modified by Bodnar, Tang, and Weintrop (1998). We compute the percentage difference between a firm's value of total capital (market value of equity plus book value of debt) and the sum of the imputed values of its industrial segments as stand-alone domestic firms. Imputed segment values are calculated by multiplying the median ratio, for single-segment, purely domestic firms in the same industry, of total capital to sales for the segment. The industry median ratios are based on the narrowest SIC grouping that yields five single-segment domestic firms that have at least \$20 million in revenue in each segment and for which we bave the data necessary to compute ratios.' We sum these imputed values across the segments within the firm to obtain an estimated imputed value for the entire firm. Excess value is measured as the log of the ratio of the firm's actual value to its

\footnotetext{
'Imputed values are calculated using four-digit SIC codes for $43.2 \%$ of the sample segment-years, three-digit codes for $24.0 \%$ of the sample segment-years, and two-digit codes for $29.1 \%$ of the sample segment-years. For $3.7 \%$ of the sample segment-years we are unable to calculate an excess value. The end-result of these segments for which we are unable to obtain a five-firm comparison sample, along with missing data and extreme outliers, is that we are able to calculate excess values for only 21,142 of the original 27,287 firm-years.
} 
imputed value. Like Berger and Ofek (1995), we exclude 'extreme' excess values, defined as those observations for which actual value is either more than four times imputed value or less than one-fourth imputed value.

Table 4 presents excess value measures for a variety of subsamples defined by diversification status. In addition, we explore the possibility that the valuation effects of diversification have changed over time by presenting separate measures for the 1984-1988 and 1989-1993 subperiods. From the large amount of data presented in table 4 , several interesting observations can be made. First, overall, global diversification is associated with reduced value. The average (median) excess value for globally diversified firms is $-0.0153(-0.0394)$. However, the mean excess value of globally diversified firms does not differ significantly from that of firms that are not globally diversified, though the medians of the two subsamples do differ at the 0.10 level. In addition, subperiod results suggest that the negative excess values associated with global diversification are confined to the earlier 1984-1988 subperiod. The difference in excess values between firms that are and are not globally diversified is significant at the 0.01 level during this subperiod.

Table 4 also documents excess values for firms that are and are not industrially diversified. Overall, industrial diversification is associated with an average (median) excess value of -0.0204 $(-0.0330)$. These values differ significantiy from zero at the 0.01 level; however, neither mean nor median excess value differs significantly between the subsamples of firms that are and are not industrially diversified. As with global diversification, subperiod analysis reveals that the negative excess value associated with industrial diversification is driven by the earlicr 1984-1988 subperiod. The excess value associated with industrial diversification is significantly negative in this subperiod and the difference in excess values between firms that are and are not industrially 
diversified is significant at the 0.01 level. Thus, it appears that global and industrial diversification are associated with reductions in value in the 1984-1988 period but are valueneutral in the 1989-1993 period. This may suggest that increased monitoring from the corporate control market and/or improved corporate governance systems led those firms for which diversification reduces value to focus their operations.

Because we are interested in the relation between global and industrial diversification, we break the full sample into four subsamples: firm-years that are neither globally nor industrially diversified, firm-years that are both globally and industrially diversified, firm-ycars that are only globally diversified, and firm-years that are only industrially diversified. This further refinement yieids surprising results. Being either globally or industrially diversified is associated with significant negative excess value, on average, in both subperiods and being both industrially and globally diversified is associated with negative excess value in the 1984-1988 subperiod. However, being both globally and industrially diversified in the 1989-1993 subperiod is associated with strong and significant positive excess values, on average.

The results thus far suggest that, despite the fact that industrial diversification has decreased and global diversification has increased over time, they are actually complementary forms of diversification. Fims that are industrially diversified are more likely to be globally diversified (and vice versa) and, more importantly, the two forms of diversification together are valueincreasing, while either type of diversification on its own destroys value. However, the analysis to this point has been univariate in nature. In the following section we examine the effect of diversification on value in a multivariate setting. 


\subsection{Multivariate results}

To provide multivariate evidence on the valuation effects of the different types of diversification, we estimate ordinary least squares regressions of excess value on three dummy variables denoting: (i) firms that are industrially but not globally diversified; (ii) firms that are globally but not industrially diversified; and (iii) firms that are both industrially and globally diversified. Thus the regression coefficients on the dummy variables represent the difference in excess value between the firms in each diversification category and the excess values of singlesegment domestic firms.

In addition, we control for other possible determinants of excess value, including firm size, measured as the market value of total capital, the ratio of long-term debt to total assets, the ratio of capital expenditures to sales, the ratio of eamings before interest and taxes (EBIT) to sales, the ratio of research and development expenditures to sales, and the ratio of advertising expenditures to sales. Because excess values are measured relative to single-segment domestic firms, we compute relative measures of all independent variables in a similar manner. ${ }^{b}$. Where there are missing observations for research and development expenditures or advertising expenditures, we set the missing values to zero, Our results are not sensitive to this choice, however. We obtain similar results if we exclude all observations with missing data.

In the first column of table 5, we report the results for the full sample of 21,142 firm-year observations. Consistent with the univariate results presented in table 4 , the multivariate results presented in table 5 indicate that excess values are significantly lower for firms that are industrially or globally diversified than they are for single-segment, domestic firms. The multivariate results suggest, however, that these discounts are of larger magnitude than those

\footnotetext{
'Bodnar Tang, and Weintrop (1995) use a similar approsch. Our findings are not sensitive to this choice.
} 


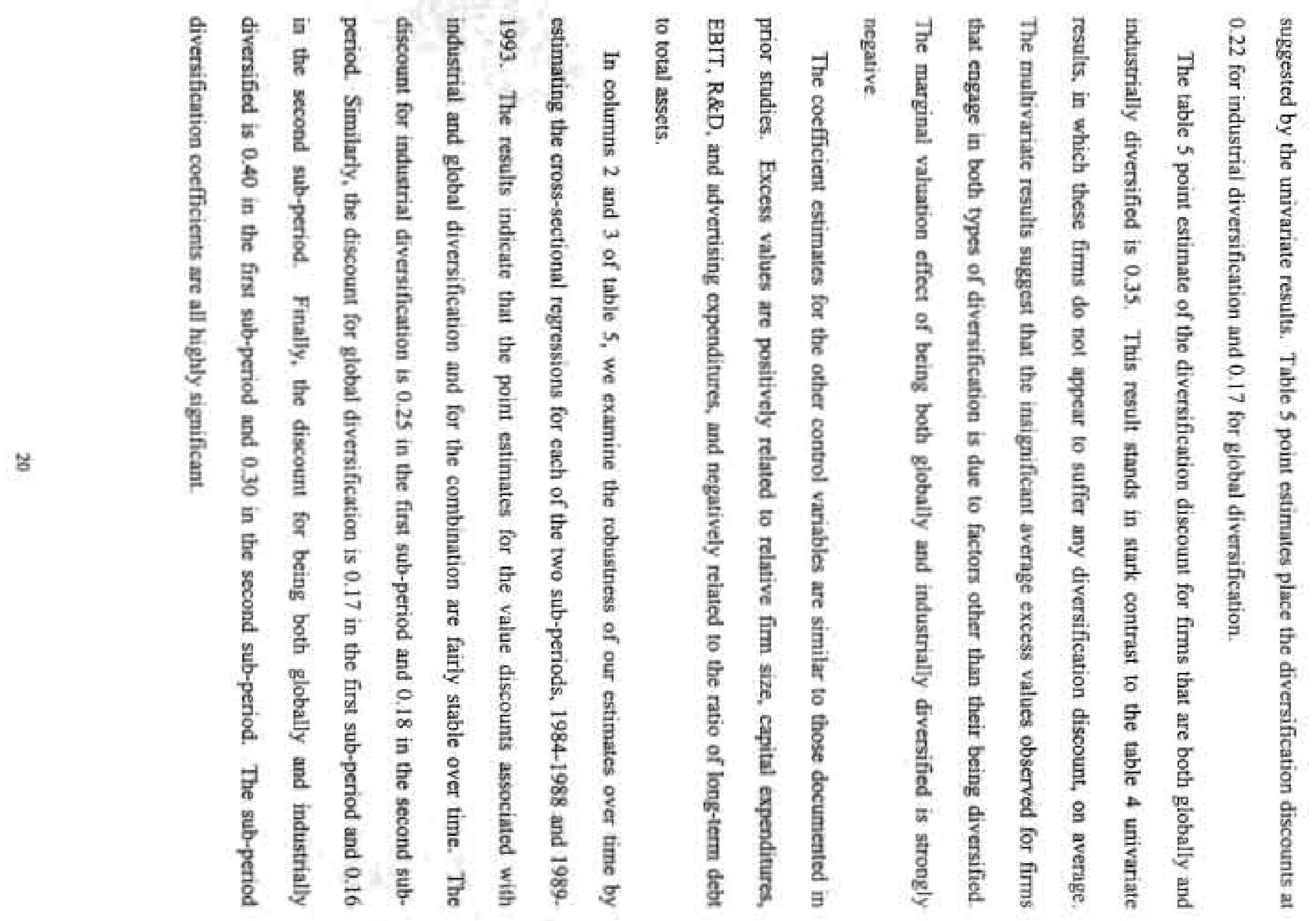




\subsection{The valuation effects of changes in diversification}

One difficulty in interpreting the valuation results in tables 4 and 5 is that our excess value measure could be endogenously related to the choice of diversification. For example, it is possible that poorly performing firms are more likely to become diversified. If so, diversified firms will exhibit lower values even if diversification per se has no impact on firm value. To address this possibility, we examine whether changes in diversification status are associated with changes in excess value. From the full sample, we identify any year in which a firm either becomes globally diversified or ceases being globally diversified, or becomes industrially diversified or ceases being industrially diversified. We label the year in which the firm's diversification status changes as year 0 and measure the change in excess value from year -1 to year 0 .

Table 6 presents year -1 excess values and changes in excess value for these four subsamples for the whole period and for the 1984-1988 and 1989-1993 subperiods. The results as a whole are largely consistent with the overall negative association between excess value and global and industrial diversification. Firms that become either globally or industrially diversified experience statistically significant decreases in excess value and firms that cease being either globally or industrially diversified experience statistically significant increases in excess value, where statistical significance is at at least the 0.10 level. This result holds for the whole sample period and for each of the subperiods, with the following exceptions. The median change in excess value associated with ceasing to be globally diversified in the overall period is positive but not significantly different from zero at the 0.10 level. In addition, becoming globally diversified in the 1984-1988 subperiod is associated with a statistically insignificant change in excess value, as is ceasing to be globally diversified in the 1989-1993 subperiod. 
Thus, the table 6 results suggest that firms generally experience significant declines in excess value in a year in which they become diversified. In addition, data on year -1 excess values suggest that firms generally have significantly positive excess value in the year before they diversify globally, and insignificant excess value in the year prior to becoming industrially diversified. Thus, the observed valuation discounts associated with global and industrial diversification are not due simply to poorly-performing firms choosing to diversify.

\section{Conclusion}

Using a sample of 27,287 firm-years over the period 1984-1993, we document several findings with respect to global diversification, industrial diversification, and the relation between them.

We document an increasing trend in global diversification over time: a greater fraction of U.S. firms have intemational operations in 1993 than in 1984 and, on average, those firms that are multinational derive a greater fraction of their revenues from their foreign operations in 1993 than in 1984. Industrial diversification declines over the same period, although the decline in number of segments is more pronounced than the decline in the fraction of firms that are industrially diversified. However, we find no evidence that these opposing trends are related at the firm level; i.e. individual firms do not appear to substitute global for industrial diversification.

We find that both global or industrial diversification lead to valuation discounts that are economically and statistically significant relative to single-segment, purely domestic firms. This is true in both the 1984-1988 and the 1989-1993 subperiods. Firms that are either globally or industrially diversified (but not both) have negative excess values, single-segment domestic 
firms that become either globally or industrially divernified experience a downward revision in their excess value, and fims that are either globally or industrially diversified experience increases in excess value when they cease being diversified.

Thus, a presumed increase in the feasibility of global diversification over time has, in fact. led to a greater incidence and higher levels of global diversification. Increased feasibility has not, however, translated into value-ereation opportunites for the single-segment firms that comprise the majority of U.S. firms. 


\section{References}

Amihud, Yakov and Baruch Lev, 1981, Risk reduction as a managerial motive for conglomerate mergers, Bell Journal of Economics 12, 605-617.

Berger, Philip G. and Eli Ofek, 1995, Diversification's effect on firm value, Journal of Financial Economics 37, 39-65.

Bodnar, Gordon M., Charles Tang, and Joseph Weintrop, 1998, Both sides of corporate diversification: The value impacts of global and industrial diversification, Working paper, University of Pennsylvania.

Caves, Richard, 1971, International corporations: The industrial economics of foreign investment, Econometrica 38, 1-27.

Christophe, Stephen E., 1997, Hysteresis and the value of the U.S. multinational corporation, Journal of Business $70,435-462$.

Christophe, Stephen E. and Ray J. Pfeiffer, Jr., 1998, The valuation of U.S. MNC international operations during the 1990s, Working paper, George Mason University.

Comment, Robert and Gregg A. Jarrell, 1995, Corporate focus and stock returns, Journal of Financial Economics 37, 67.87.

Denis, David J., Diane K. Denis, and Atulya Sarin, 1997, Agency problems, equity ownership, and corporate diversification, Journal of Finance 52, 135-160.

Denis, David J. and Bharathram Thothadri, 1999, Intemal capital markets, growth opportunities and the valuation consequences of diversification, Working paper, Purdue University.

Errunza, Vihang and Lemma Senbet, 1981, The effects of international operations on market value of the firm: Theory and evidence, Journal of Finance 36, 401-417.

Errunza, Vihang and Lemma Senbet, 1984, International corporate diversification, market valuation, and sixe-adjusted evidence, Journal of Finance $34,727-745$.

Harris, Milton, Charles D. Kricbel, and Artur Raviv, 1982, Asymmetric information, incentives and intrafirm resource allocation, Management Science 28, 604-620.

Jensen, Michael C., 1986, Agency costs of free cash flow, corporate finance, and takeovers, American Economic Review 76, 323-329.

Jensen, Michael C., 1993, The modern industrial revolution, exit, and the failure of internal control systems, Journal of Finance 48, 831-880. 
Jensen, Michuel C. and Kevin J. Murphy, 1990, Performance pay and top management incentives, Journal of Political Economy 98, 225-264.

Lang. Larry H. P. and René M. Stulz, 1994, Tobin's q, corporate diversification and firm performance, Journal of Political Economy 102, 1248-1280.

Liebeskind, Julia P. and Tim C. Opler, 1994, Corporate diversification and agency costs: Evidence from privately held firms, Working paper, Ohio State University.

Myer, Margaret, Paul Milgrom, and John Roberts, 1992, Organizational prospects, influence costs, and ownership changes, Journal of Economics and Management Strategy 1, 9-35.

Myerson, Roger B., 1982, Optimal coordination mechanisms in generalized principal-agent problems, Journal of Mathematical Economics 10, 67-81.

Morck, Randall and Bemard Yeung, 1991, Why investors value multinationality, Journal of Business 64, 165-187.

Morck, Randall and Bernard Yeung, 1998, Why investors sometimes value size and diversification: The internalization theory on synergy, Working paper, Institute for Financial Research, University of Alberta.

Rajan, Raghuram G., Henri Servaes, and Luigi Zingales, 1999, The cost of diversity: the diversification discount and inefficient investment, Joumal of Finance, forthcoming.

Rajan, Raghuram G. and Luigi Zingales, 1995, The tyranny of the inefficient: An inquiry into the adverse consequences of power struggles, Working paper, University of Chicago.

Scharfstein, David S., 1997. The darker side of internal capital markets II: Evidence from diversified conglomerates, Working paper, Massachusetts Institute of Technology.

Scharfstein, David S, and Jeremy C. Stein, 1997, The dark side of intemial capital markets: Divisional rent-seeking and inefficient investment, Working paper, National Bureau of Economic Research.

Shin, Hyun-Han and René M. Stulz, 1998, Are intemal capital markets efficient?, Quarterly Journal of Economics 113, 531-552.

Shleifer, Andrei and Robert Vishny, 1991. The takeover wave of the 1980s, Journal of Applied Corporate Finance 4, 49-56.

Servaes, Henri, 1996, The value of diversification during the conglomerate merger wave, Journal of Finance $51,1201-1225$.

Stein, Jeremy C., 1997, Internal capital markets and the competition for corporate resources, Journal of Finance 52, 111-133. 
Stulz, René M., 1990, Managerial discretion and optimal financing policies, Journal of Financial Economics 26, 3-27, 
Table 1

Descriptave statistics on size and diversificanian measures for 27,267 firm-years over the period 1984-1993.

\begin{tabular}{|c|c|c|c|c|c|c|}
\hline & \multicolumn{2}{|c|}{$\begin{array}{c}\text { All Firm Years } \\
(\mathrm{n}=27,287)\end{array}$} & \multicolumn{2}{|c|}{$\begin{array}{l}\text { Industrially } \\
\text { Divervified } \\
(0=5,545)\end{array}$} & \multicolumn{2}{|c|}{$\begin{array}{c}\text { Globally } \\
\text { Divernified } \\
(n=8,087)\end{array}$} \\
\hline & Mean & Median & Mean & Median & Mean & Medias \\
\hline $\begin{array}{l}\text { Book value of total assets } \\
\text { ( } \$ \text { millions) }\end{array}$ & $\$ 973,9$ & $\$ 126.8$ & $\$ 2,629.1$ & $\$ 653,6$ & $\$ 1.750 .6$ & 5250.4 \\
\hline Annual sales (\$ millions) & $\$ 985.2$ & $\$ 159.3$ & $\$ 2,540.4$ & 5770.1 & $\$ 1,742.7$ & $5288 ?$ \\
\hline \multicolumn{7}{|l|}{$\begin{array}{l}\text { Industrial diversification } \\
\text { measures: }\end{array}$} \\
\hline $\begin{array}{l}\text { Fraction of firm-years } \\
\text { industrially diversified }\end{array}$ & 0.20 & & 1.00 & & 0.33 & \\
\hline Number of segments & 1.39 & 1.00 & 2.91 & 3,00 & 1.68 & 1.00 \\
\hline $\begin{array}{l}\text { Sales based Herfindahl } \\
\text { index }\end{array}$ & 0.90 & 1.00 & 0.52 & 0.51 & 0.84 & 1.00 \\
\hline \multicolumn{7}{|l|}{$\begin{array}{l}\text { Global diversification } \\
\text { meanures }\end{array}$} \\
\hline $\begin{array}{l}\text { Frnction of firm-years } \\
\text { elobally diversified }\end{array}$ & 0.30 & & 0.48 & & 1.00 & \\
\hline Fraction foreiga sales & 0.08 & 0 & 0,11 & 0 & 0.26 & 0.22 \\
\hline
\end{tabular}


Table 2

Average annual industrial and global diversification mieasures for 27,287 firm-years over the period 1984 . 1993. The number of industrial segments and Herfindahl measures are for the subsample of firms that are industrially diversified. The fraction foreigm sales measure is for the subsample of firms that are globally divernified. The conatant composition ample includes those firms for which there is Compuatat data available throughout the entire 1984-1993 period.

Panel A. Fuill Sample

\begin{tabular}{|c|c|c|c|c|c|c|}
\hline \multirow[b]{2}{*}{ Yeat } & \multirow[b]{2}{*}{$\mathrm{N}$} & \multicolumn{4}{|c|}{$\begin{array}{l}\text { Indusmatly diverified } \\
\text { firmercars saly }\end{array}$} & \multirow{2}{*}{$\begin{array}{l}\text { Globally } \\
\text { divernifitos } \\
\text { fimarangenly } \\
\text { Fraction } \\
\text { Foreign Sales }\end{array}$} \\
\hline & & $\begin{array}{l}\text { Fraction Ind'l } \\
\text { Diversified }\end{array}$ & $\begin{array}{l}\text { s Ind' } \\
\text { Segments }\end{array}$ & $\begin{array}{l}\text { Sales-based } \\
\text { Herfindahl }\end{array}$ & $\begin{array}{l}\text { Fraction Geog } \\
\text { Diversified }\end{array}$ & \\
\hline 1984 & 2,250 & 0.262 & 3.15 & 0.49 & 0.295 & 0.212 \\
\hline 1985 & 2,415 & 0.243 & 3.09 & 0.50 & 0.284 & 0.219 \\
\hline 1986 & 2,534 & 0.230 & 2.98 & 0.51 & 0.288 & 0.243 \\
\hline 1987 & 2,665 & 0.214 & 2.93 & 0.51 & 0.286 & 0.254 \\
\hline 1988 & 2.655 & 0.209 & 2.91 & 0.53 & 0.291 & 0.269 \\
\hline 1959 & 2.668 & 0.200 & 2.87 & 0.53 & 0.295 & 0.275 \\
\hline 1990 & 2.736 & 0.192 & 2.85 & 0.53 & 0.301 & 0.290 \\
\hline 1991 & 2,875 & 0.182 & 2.76 & 0.54 & 0.305 & 0.280 \\
\hline 1992 & 3,110 & 0.171 & 2.78 & 0.54 & 0.310 & 0.283 \\
\hline 1993 & 3,370 & 0.161 & 2.74 & 0.54 & 0.303 & 0.278 \\
\hline
\end{tabular}

Panel B. Constant composition sample

$\begin{array}{lllllll}1984 & 1.169 & 0.291 & 3.18 & 0.49 & 0.323 & 0.219 \\ 1985 & 1.125 & 0.279 & 3.11 & 0.50 & 0.326 & 0.217 \\ 1986 & 1.120 & 0.282 & 3.04 & 0.50 & 0.345 & 0.241 \\ 1987 & 1.111 & 0.267 & 3.02 & 0.50 & 0.355 & 0.255 \\ 1988 & 1.103 & 0.270 & 2.93 & 0.52 & 0.365 & 0.271 \\ 1989 & 1.092 & 0.270 & 2.90 & 0.52 & 0.368 & 0.279 \\ 1990 & 1.112 & 0.270 & 2.89 & 0.53 & 0.375 & 0.295 \\ 1991 & 1.122 & 0.269 & 2.54 & 0.53 & 0.390 & 0.292 \\ 1992 & 1.143 & 0.265 & 2.88 & 0.53 & 0.403 & 0.290 \\ 1993 & 1.169 & 0.267 & 2.44 & 0.54 & 0.403 & 0.290\end{array}$




\section{Table 3}

Correlations among measures of global and industrial diverifification for a total sample of 27,287 firm-years und various subsamples. Panel A presents correlations among diversification levels; pantel B presents correlations among changes in diversification in individual firm-years, and panel $\mathrm{C}$ presents correlations among changes in diversification between 1984 and 1993 for the subsample of firms that are included in the sample in both 1984 and 1993

Panel A Correlations benween firm-year levels of glabal and industrial diversification

\begin{tabular}{|c|c|c|c|}
\hline & Full Sample & Gdum-1 & Indium =1 \\
\hline Gdum/Indum & 0.1992 & NA & NA \\
\hline Gdum/Segn & $0.2063^{\ldots}$ & NA & $0.1500^{* * *}$ \\
\hline \%aforlindum & $0.1166^{\circ-2}$ & $-0.0865^{t+1}$ & $\mathrm{NA}$ \\
\hline \%For/Sega & $0.1146^{* *}$ & $-0.0924^{t+1}$ & $0.0689^{* . *}$ \\
\hline
\end{tabular}

Panel B Correlations between firm-year changes in global and industrial diversifcarion

\begin{tabular}{|c|c|c|c|c|c|}
\hline & Full Sample & LGdum 0 & LGdum=1 & Lindume0 & Hndum=1. \\
\hline$\Delta G$ Gumviladum & $0.0580^{\circ 12}$ & 0.0063 & $0.1677^{27}$ & $0.0135^{\circ}$ & $0.1183^{n .}$ \\
\hline$\Delta G$ dum/aSegn & $0.0623^{*+*}$ & 0.0097 & $0.1403^{.04}$ & 0.0076 & $0.1204^{300}$ \\
\hline$\Delta \%$ Forislndum & 0.0112 & 0.0026 & $0.0226^{\circ}$ & 0.0069 & 0.0163 \\
\hline$\Delta \%$ For'sSegn & $0.0135^{* *}$ & 0.0044 & $0.0239^{\circ}$ & -0.0003 & $0.0304^{\circ}$ \\
\hline$\Delta G d u m$ L.Indum & $-0.0198^{* * *}$ & $0.0287^{* * *}$ & $-0.0341^{\circ+4}$ & NA & $\mathrm{NA}$ \\
\hline$\Delta \%$ For/LIndum & -0.0104 & 0.0034 & $-0.0522^{* * *}$ & $\mathrm{NA}$ & NA \\
\hline Alndurn/LGdum & $-0.0189^{* * *}$ & NA & NA & $0,0143^{\circ}$ & $0.0272^{\circ}$ \\
\hline$\Delta$ Segn/LGdum & $-0.0363^{\cdots}$ & NA & NA & $0.0145^{\circ}$ & -0.0201 \\
\hline
\end{tabular}

Panel $C$ Correlations berween changes in global and indussrial diversification berween 1984 and 1993 jor cansiam? compasinion subsample

\begin{tabular}{|c|c|c|c|c|c|}
\hline & Full Sampie & $84 G$ dummo & 84Gidum-1 & 84 Indum $=$ ? & 84indume-1 \\
\hline$\Delta G$ dumv/ndum & 0.0210 & -0.0256 & 0.0815 & 0.0272 & 0.0190 \\
\hline$\Delta G$ dumv $\Delta$ Segn & 0.0245 & $-0.0707^{* *}$ & $0.1243^{*-}$ & 0.0067 & 0.0465 \\
\hline$\Delta \%$ For/Alndium & $-0,0400$ & -0.0154 & -0.0581 & $-0,0321$ & -0.0481 \\
\hline$\Delta \% F o r / \Delta S e g a$ & 0.00077 & -0.0201 & 0.0251 & -0.0410 & 0.0344 \\
\hline AOdumselindum & $-0,0003$ & $0.1116^{* *}$ & 0.0034 & $\mathrm{NA}$ & NA \\
\hline$\Delta \%$ For/34Indum. & 0.0164 & 0.0079 & $-0.0389^{\circ}$ & NA & $\mathrm{NA}$ \\
\hline Alndum/84Cdum & $-0.0556^{\circ}$ & NA & $\mathrm{NA}$ & -0.0210 & $0.1256^{\circ}$ \\
\hline$\Delta$ Segn/84Gdum & $-0.0816^{\cdots *}$ & NA & $\mathrm{NA}$ & -0.0015 & 0.0303 \\
\hline
\end{tabular}

\footnotetext{
Varibble definitions:

Gdum A dummy variable $=$ to $I$ if the firm is globally diversified in the given year and 0 otherwise.

Indum A durmony variable $m$ I if the firm is industrially diversified in the given year and 0 otherwise.

\%For The percentage of the firm's sales derived from foreign operations in the given year-

Segn The number of industrial segments in the firm in the given year.

LGdum A dummy yariable = to $I$ if the firm is globally diversified in the year prior to the given year and 0 otherwise.

Lindum A dummy variabie $=$ to $I$ if the firm is industrially diversified in the year prior to the given year and 0 otherwise.

84Gdum A dummy variabie $=$ to $I$ if the firm is globally diversified in 1984 and 0 otherwise.

84lindum A dummy variable $=$ to $I$ if the firm is industrally diversified in 1984 and 0 otherwise-

$\cdots,+$, and ${ }^{*}$ denote signifieance at the $0.01,0.05$, and 0.10 level, respectively.
} 
Table 4

Mesa and median excess value associated with firm-yean for which the data required to calculate excesa value is availabie. Excess value is measued as the log of the ratio of the firm's iotal matket value so the sum of the imputed market valies of its segments. Imputed segment valoes are calculated by multiplying the median ratio of total capital to sales for single segment domestie firms in the same industry times the level of saies for the isdividual segment. Significance of meani and medians are measured uting a standard two-tailed t-test and a two-tailed Wilcoxon signed rank tert, respectively.

\begin{tabular}{|c|c|c|c|c|c|}
\hline Einm-yents that ane: & & $\frac{1984+1993}{(0-21,142)}$ & $\frac{1984.1988}{(N=0.96)}$ & $\frac{1989-1993}{(N-11, j 00)}$ & $\begin{array}{l}\text { p-values for } \\
\text { significance } \\
\text { of subperiod } \\
\text { differences }\end{array}$ \\
\hline \multirow[t]{4}{*}{ Globully diverafied } & Mean & $0.0153^{-*}$ & $-0.0327^{*}$ & .0 .0007 & 0.0145 \\
\hline & Median & $0.0394^{-2}$ & $-0.0671^{+\cdots}$ & -0.0162 & 0.0080 \\
\hline & $\mathrm{N}$ & 6,618 & 3,018 & 3,600 & \\
\hline & $\%$ & $313 \%$ & $30.4 \%$ & $32.1 \%$ & \\
\hline \multirow[t]{4}{*}{ Not globally diversified } & Mean & $=0.0066$ & -0.0038 & -0.0092 & 0.5136 \\
\hline & Median & $0.0000^{* * *}$ & $0,0000^{\circ}$ & $0.0000^{*}$ & 0.5655 \\
\hline & $\mathbf{N}$ & 14,524 & 6,924 & 7,6000 & \\
\hline & $\%$ & $68.7 \%$ & $69.6 \%$ & $67.9 \%$ & \\
\hline \multirow[t]{4}{*}{ Industrially diversified } & Meas & $-0.0204^{* \ldots}$ & $-0.0520^{\mathrm{co*}}$ & 0.0157 & 00000 \\
\hline & Median & $-0.0330^{-2}$ & $.0 .0710^{* 2+}$ & 0.0106 & 0.0001 \\
\hline & $\mathrm{N}$ & 4,029 & 2,150 & 1,879 & \\
\hline & \% & $19.1 \%$ & $21.6 \%$ & $16.8 \%$ & \\
\hline \multirow[t]{4}{*}{ Not industrally diversified } & Mean & $-0.0067^{\circ}$ & -0.0017 & $-0.0109^{-}$ & 0.2440 \\
\hline & Median & $0.0000^{\cdots}$ & 0.0000 & $0.0000^{* *}$ & 0.2279 \\
\hline & $\mathrm{N}$ & 17,113 & 7,792 & 9,321 & \\
\hline & $\%$ & $80.9 \%$ & $78.4 \%$ & $83.2 \%$ & \\
\hline \multirow{4}{*}{$\begin{array}{l}\text { Both globally and } \\
\text { isdustrially diversified }\end{array}$} & Mean & 0.0108 & $-0.0488^{\ldots *}$ & $0.0761^{\ldots+\ldots}$ & 0.0000 \\
\hline & Median & $-0,0092$ & $-0.0690^{* * *}$ & $0.0498^{* * *}$ & 0.0001 \\
\hline & $\mathrm{N}$ & 1,939 & 1,013 & 926 & \\
\hline & $*$ & $9.2 \%$ & $10.2 \%$ & $8.3 \%$ & \\
\hline \multirow{4}{*}{$\begin{array}{l}\text { Neither industrially not } \\
\text { globally diversified }\end{array}$} & Meas & 0.0006 & 0.0062 & -0.0043 & 0.2405 \\
\hline & Median & 0,0000 & 0.0000 & 0.0000 & 0.2043 \\
\hline & $\mathrm{N}$ & 12.434 & 5,787 & 6,647 & \\
\hline & $\%$ & $58.8 \%$ & $58.2 \%$ & $59.3 \%$ & \\
\hline \multirow{4}{*}{$\begin{array}{l}\text { Globally diversified } \\
\text { but not industriaily diversified }\end{array}$} & Mean & $-0.0261_{\ldots+4}^{\ldots+4}$ & $-0.0246^{\circ *}$ & $-0.0273^{\circ}$ & 0.8715 \\
\hline & Median & $-0.0546^{\ldots *}$ & $-0.0660^{\circ-*}$ & $-0.0485^{* 2 .}$ & 0.9109 \\
\hline & $\mathrm{N}$ & 4,679 & 2,005 & 2,674 & \\
\hline & $\%$ & $22.1 \%$ & $20.2 \%$ & $23.9 \%$ & \\
\hline \multirow{4}{*}{$\begin{array}{l}\text { Industrially divenified } \\
\text { but not globally } \\
\text { diversified }\end{array}$} & Mean & $-0.0494^{* 6 *}$ & $.0 .0548^{\prime 2 *}$ & $-0.043 t^{m *}$ & 0,5729 \\
\hline & Median & $-0.0510^{2 * *}$ & $-0.0744^{* 3 *}$ & $-0.0214^{m+}$ & 0.3274 \\
\hline & $\mathbf{N}$ & 2,000 & 1,137 & 953 & \\
\hline & $\%$ & $9.9 \%$ & $11.4 \%$ & $8.5 \%$ & \\
\hline
\end{tabular}

$\cdots, .$. , and ${ }^{*}$ denote sugnificance at the $0.01,0.05$, and 0.10 level, respectively. 


\section{Tabies}

Ordinary least squares regrestions of sxcen vahe on dummy varables denoting indutrial and glsbal diversification, and a set of control variables. Excess value is measured as the log of the ratio of the firm'r total market value to the sum of the iniputed matket values of its sezments. Impated segment values are calculated by multiplying the median ratio of total capital to salen for single segment domestic firms in the same indurstry times the level of sales for the individual segment. A firm is indastrially diversified if it reports more than one industrial buainess segment. Likewise, a firm is globally divenified if it reports operations in more than one global batinen sejment. All control variables are measured as deviations from saled-weighted industry median values. The sample includes 21,142 fimm-year observations over the period 1984-1993. Coefficient estimates are reported witb f. statistics in parentheses below. Results are reparted for the full sample of firm-years, the sub-periods of 1984-88 and 1989-93, and mean values of anmual regrestions.

\begin{tabular}{|c|c|c|c|c|c|}
\hline Independent variables & & Full sample & 1984 to 1988 & 1989 to 1993 & $\begin{array}{c}\text { Means of } \\
\text { annual } \\
\text { estimates }\end{array}$ \\
\hline Intercept: & & $\begin{array}{c}0.004 \\
(0.964)\end{array}$ & $\begin{array}{l}0.006 \\
(1.034)\end{array}$ & $\begin{array}{c}0.003 \\
(0.460)\end{array}$ & $\begin{array}{r}0.003 \\
(1.221)\end{array}$ \\
\hline $\begin{array}{l}\text { Duminy equal to one if only } \\
\text { indestrially diversified }\end{array}$ & & $\begin{array}{c}-0.218 \\
(-20.167)\end{array}$ & $\begin{array}{r}-0.245 \\
(-16.538)\end{array}$ & $\begin{array}{c}-0.184 \\
(-11.692)\end{array}$ & $\begin{array}{r}0.210 \\
(-16.735)\end{array}$ \\
\hline $\begin{array}{l}\text { Dumany equal to one if only } \\
\text { globally diversified }\end{array}$ & & $\begin{array}{c}-0.168 \\
(-21,462)\end{array}$ & $\begin{array}{c}-0.170 \\
(-14.636)\end{array}$ & $\begin{array}{c}-0.160 \\
(-15.169)\end{array}$ & $\begin{array}{r}0.162 \\
(-15.136)\end{array}$ \\
\hline $\begin{array}{l}\text { Dummy equal to one if both } \\
\text { industrially and globally tivenified }\end{array}$ & & $\begin{array}{c}-0.350 \\
(-28.387)\end{array}$ & $\begin{array}{c}-0.397 \\
(-23328)\end{array}$ & $\begin{array}{c}-0.295 \\
(-16.708)\end{array}$ & $\begin{array}{c}-0.340 \\
(-18.329)\end{array}$ \\
\hline Relative market value of total capital & & $\begin{array}{c}0.132 \\
(56.535)\end{array}$ & $\begin{array}{c}0.131 \\
(38.473)\end{array}$ & $\begin{array}{c}0.128 \\
(40.418)\end{array}$ & $\begin{array}{r}0.128 \\
(67.758)\end{array}$ \\
\hline Relative long-term debt to total assets & & $\begin{array}{r}-0.350 \\
(-17.398)\end{array}$ & $\begin{array}{c}-0.182 \\
(-6.079)\end{array}$ & $\begin{array}{c}-0.475 \\
(-17.601)\end{array}$ & $\begin{array}{c}-0.344 \\
(-5.291)\end{array}$ \\
\hline Relative capital expenditures to sales & & $\begin{array}{c}0.397 \\
(18.517)\end{array}$ & $\begin{array}{c}0.392 \\
(14,077)\end{array}$ & $\begin{array}{c}0.372 \\
(11.269)\end{array}$ & $\begin{array}{l}0.446 \\
(2.856)\end{array}$ \\
\hline Relative EBIT te sales & & $\begin{array}{r}1.109 \\
(38.474)\end{array}$ & $\begin{array}{c}0.867 \\
(23.512)\end{array}$ & $\begin{array}{c}1.490 \\
(32.760)\end{array}$ & $\begin{array}{r}1.210 \\
(11.045)\end{array}$ \\
\hline Relative RAD to sales & & $\begin{array}{c}1.172 \\
(17.935)\end{array}$ & $\begin{array}{r}1.506 \\
(13.958)\end{array}$ & $\begin{array}{r}1,043 \\
(12.745)\end{array}$ & $\begin{array}{c}1.358 \\
(12.933)\end{array}$ \\
\hline Relative advertiaing to sales & & $\begin{array}{c}0.211 \\
(2.116)\end{array}$ & $\begin{array}{l}0270 \\
(1911)\end{array}$ & $\begin{array}{l}0.154 \\
(1.108)\end{array}$ & $\begin{array}{l}0.221 \\
(3.238)\end{array}$ \\
\hline Adjusted $\mathrm{R}^{2}$ & & 0.282 & 0262 & 0311 & 0.291 \\
\hline
\end{tabular}




\section{Table 6}

Excess values for finns that change their divenification stanus between 1994 and 1993. Year -1 levels and the change in excess value froen year -1 to year 0 ast presented. Year 0 is the year in which the firm changes is divenification status. Excess valve is measured as the log of the ratio of the firm's total market value to the sum of the imputed market values of its segnents. Imputed segment values ate calculated by multiplying the median ratio of total capital to saies for stangle scement domestic firms in the same industry times the level of ales for the individaal seiment. Panel A presents results for the full sample, while pasels B and C present rmalts for the 1984-1988 and 1989-1993 subperiods. Significance of means and mediant are mearured using a standard two-tailed test and a two-biled Wilcoxon signed rank tess, iryectively.

Panel A Full Sampie

Panel a Fulf Sampie

Became globally drvensied

Ceased global diverification

Became industrially divernified

Ceased industral diversification

$\frac{\text { Year-1 Excess Vahur }}{\text { Mean }}$

$0.112^{* * *}$

$$
0.097^{* \cdots}
$$

$-0006$

.0 .074

0.013

0.015

$-0.084^{*-}$

$-0.118^{* *}$
A Fxcess Value Meas Median

$-0.043^{\circ}-0.045^{\circ}$

$0.100^{\circ} \quad 0.093$

$-0.197^{* \cdots} \quad-0.183^{* \cdots}$

$0.178^{\cdots}$

$0.156^{* 0 *}$

Panel B. 1984-1988

Became globally diverufied 126 0.018 0.000 0.042 0.072

Ceased global diverafication 44

$-0.117$

$-0.072$

$0.194^{* *}$

$0.187^{* *}$

Became industrially diversified 39

$-0.001$

0.018

$-0.158^{\circ *}$

$-0.100 \%$

Ceased modustrial diverufication

86

$-0.136^{* \cdots}$

$-0,201^{* \cdots}$

$0.199^{* * *}$

$0.131^{* * *}$

Panel C /959-/993

Became globally diversified

Ceased global diversification

Became industrially diversified

Ceased industrial diversification
168

50

48

73

48.

$0.180^{-10}$

$-0.037$

0.026

$-0.023$ $0.182^{\cdots+\cdots}$

$-0.106^{* * *}$

$-0.110^{* . *}$

This represents the number of firms for which we are abie to calculate a cha
... and
0.026

0.018

.0 .009

0.000

$-0.230^{* * *}$

$-0.202^{* * *}$

0.002

$0.154^{20 *}$

$0,175^{* * *}$ 
No. 93-101 Gordon M. Phillips, and Robert J. Weiner

"Informatian and Narmal Bachwardation as Determinanas of Trading Performance: Evidence from the North-Sea Oil Forward Market, "1994. The Fconomic Journal.

No. 93-102 Stephen R. Goldberg and Frank L. Heflin

"The Association Befween the Level of International Diversification and Risk."

No. 93-103 John A. Carlson

"Rlsk Aversion, Foreign Exchange Speculation and Gambler's Ruin."

No. 93-104 John A. Carlson, Aasim M. Husain, and Jeffrey A. Zimmerman

"Penalties and Exclussion in the Rescheduling and Forgiveness of International Loans,"

No. 93-105 Kent D, Miller

"Industry and Country Effects an Menager's Penceptions of Environmental Uncertuinties."

1993. Journal of International Butiness Studies, 24: 693-714.

No. 93-106 Stephen R. Goldberg and Joseph H. Gedwin

"Foreign Currency Translation Under Twe Cases-Jintegrated and Isolated Ecanomies"

No. 93-107 Kent D. Miller

"A Comparison of Managers' Uncertaing Peropptions and Country Rish Indices."

No. 93-108 Jon D. Haveman

"The Effect of Trade Induced Displacement on Unemployment and Wages."

No. 93-109 Jon D. Haveman

"Some Welfare Effects of Dynamic Cusioms Union Formation."

Na. 93-110 John A. Carlson and lasook Kim

"Central Banks' Expected Profin Fram Interwention."

Na. 94-001 Casper G. De Vries, Phillip A. Stork, and Kees G. Koedijk

"Between Realignments amd Imterventionz The Belgian Franc in the Eurapean Monetary System."

No, 94-002 Casper G. de Vries asd K. U. Leuveli

"Stylised Facts of Naminat Exchange Rate Returns"

No. 94-003 Kent D. Miller

"Operational Flexibility Respanies to Envirommental Uncertainties."

No. 94-004 Kent D. Miller

"Economic Exposure and Integrated Risk Management."

No. 94-005 Kent D. Miller

"Diversification Responses to Environmental Uncertainties."

Na. 94-006 John M. Hannon, lng-Chung Huang, and Bih-Shiaw Jaw

"International Human Resource Strutegy and Its Determinants: The Case of Multinationals and Their Subsidiaries in Taiwan." 
Na. 94-007 John M. Hannon, Ing-Chung Huang, and Bih-Shiaw Jaw

"Intermationat Hanum Researce Stratycy and Centrol: The Case of Multinationats and Their

Subshilitaries =

Ne. 94-008 John M. Hannea and Yoke Sane

"Customen-Driven Haman Resource Policies and Practices in Japan,"

No. 94-009 John A. Cartsen and Insook Kim

"Leaning Against the Hind: Do Central Banks Necessarily Lase?"

No. 94-010 John A. Cartsont abd David W. Schodt

"Beyoud the Lecture: Case Teaching and the Luarning of Econamic Theory"

No. 94-011 Alok R. Chaturvedl, Hemant K. Jain, and Derek L. Narareth

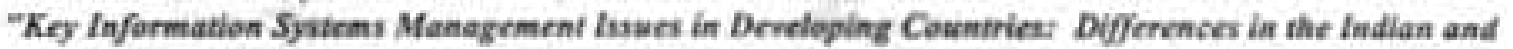
US Canteats: "

No. 94-012 Jon Haveman,

"The Influemee of Changing Trade Parterns an Displacements of Labor."

No. 94-013 Stephen Goldberg, Charles A. Tritschler, and Joseph H. Godwis

"Financial Reporting for Forelgn Exchange Derivatives."

No. 94-014 Charles Noussair, Charles Plott, and Raymand Rlezman

"Una investigacion experimental sobre la estructura del camercia interncienal (Spanish Verniank."

Translated: "An Experimental Invertigation About the Structure ef International Comimerce."

No, 94-015 Marie Thuraby and Ricbard Jeasen

"Patent Races, Product Standardt, and Internatienal Competilion,"

No. 94-016 Kent D. Miller and Jeffrey J. Reuer

"Firm Strategy and Economic Exposure to Forrign Exchange Rate Mowements."

No. 94-017 John Hannon and Yoke Sano

"The Determinants of Corporate Attroctiveness in Japan,"

No. 94-018 John Hannon, Ing-Chung Huang, and Cheng-Chen Lis

"The Mediating Effect of PrePast Assigmanem Acitivities on the Quality of Work Life of Expatriates:

Evidence for Managers in the P.R.C."

No. 94-019 John Hannon, Ing-Chung Huang, and Cheng-Chen Lin

"The Mediating Epfects of Organitation Commitment and.Job Imvolvement on the Relationship Denvecn Quality of Work Life and Cmstomer Sendec Amitudes,"

No.94-020 John A. Carlson and Mare Surchat

"A Model for Fither-Rule Gains in Foreign Exchange Markets."

No. 94-021 Ch.N. Noussair, Ch.R. Plott, and R. Rlezman

"The Principles of Exchange Rate Determination in an International Finance Experiment."

No. 94-022 Stephen R. Goldberg, Joseph II, Godwin, Myung-Sun Kim, and Charles A. Tritschler

"On The Determinasis of Corporate Hedging Wih Financlal Derivatives."

No. 95-001 Thmothy B. Folta

"Sovereignoy Condirloni and Governance Modest An Optlon Theary Approach."

No. 95-002 Johe A. Cartson and Deng-Geun Han

"Monetary Coordination, Fixed Exchange Rates and Noivy Marken." 
No. 95-004

No. 95-005

No. 95-006

No. $95-007$

No. $96-001$

No. $96-002$

No. 96-003

No. 96-004

No. 96-005

No. 96-006

No. 96-007

Ne: $96-008$

No. 96-009

No. $96-010$

No. 96-011

No. 96-012

No. 96-013
Kent D. Miller and Jeffrey J. Reuer

"Asymmetric Corporate Exposures to Foreign Exchange Rates."

Gerald J. Lynch and Bradley T. Bwing

"Money Growth Variability and the Term Structure of Interest Rates in Japan."

Nicholas C. Petruzzi and Maqbool Dada

"Inventory and Pricing in Global Operations: Learning from Observed Demand."

Kala Krishna and Maric Thursby

"Whither Flat Panel Displays?"

Thomas Brush, Catherine Maritan, and Aneel Karnani

"Managing a Network of Plants Within Multinational Firms."

John J. McConnell, Heidi J. Dybevik, David Haushalter, and Erik Lie

"A Survey on Domestic and International Stock Exchange Listings with Implications for Markets and Managers."

Kala Krishna, Suddhasatwa Roy, and Marie Thursby

"Implementing Market Access."

Jon Haveman, David Hammels

"Trade Creation and Trade Diversion: New Empirical Results."

Riki Takeuchi, John M. Hannon

"Antecedents of Expatriate Spouse Adjustments: An Analysis of Japanese Spouses in the United States."

Bih-Shiaw Jaw, John M. Hannon

"Determinants of International and Intercultural Human Resource Control: The Case Of Taivanese Subsidiaries in the People's Republic of China."

John M. Hannon, Riki Takeuchi

"Adjustment and Job Satisfaction as Antecedents of Intent to Stay: The Case of Japanese Expatriates in the United States."

John M. Hannon

"Using International Human Resource Management to Inform the Business Intelligence Function."

Jeffrey J. Reuer, Kent D. Miller

"Agency Costs and the Performance Implications of International Joint Venture Internalization."

Neven Valev

"International Lending by U.S. Banks."

Kala Krishna, Marie Thursby, and Suddhasatwa Roy

"Implementing Market Access," (revised)

Jon D. Haveman

"The Effect of Trade Induced Displacement on Unemployment and Wages,"

Robert A. Buckle and John A. Carlson

"Inflation and Asymmetric Price Adjustment." 
Ne. 97-001

No. 97-002

No. 97.003

No. 97-004

No. 97-005

No. 97.006

No. 97-007

No. 97-008

$\mathrm{Na} .97-\mathrm{ees}$

No. $98-001$

No. $98-002$

Ne. $98-003$

No. 98-004

Ne. 98-005

No. 98-006

No. 98-007

No. 98-008

No. 99-001
Jeffrey J. Reuer

"Shareholder Weatth Effeets of Joint Venture Termination: A Transaction Cost Anatysis."

Jon Haveman and David Humaels

"What Can We Learn from Bllateral Trade? Gravity and Beyond."

Douglas Bowman, John U. Farley, and David C. Schmithein

"Cross-National Empirical Generalization of a Supplier Selection and Usage Model for Foreign

Exchange Services:"

Kent D. Miller

"Measurement of Perceived Envirunmental Uncertaintics: Respense and Extensive."

John A. Cerisen, C. O. Osler

"Rational Speculators and Exchange Rate Volatifitgs."

Marie Thurnby, Kala Krishua, and Suddhasatwu Roy

"Procompetitive Market Access," Forthconing, Business and Economics for the 21 " Century, VoL 1.

John A. Carlson

"Currency Boands, Expectatiens and Inflation Persistence."

Jon Haveman, Usba C. Nair, and Jerry G. Thursby

"The Effects of Protection on the Pattern of Trade: A Disaggregatwd Anabysis," Forthcoming, Business and Economics for the $21^{* \prime}$ Craturn Vol. 1.

George Horwich

"Ecomonic Lestons of the Kobe Earthinake."

John J. MeConnell, Kenneth A. Carow, and Gayle R. Erwin

"Financing Publicty Traded ULS. Corponations in Public and Prinate Securio Marnets, 1970-1997:

Where, How, How Mach, With What, When, and Why."

Timothy N. Cason, Tatsuyoshi Saijo, and Takehiko Yamato

“Voluntary Participarion and Spite in Public Good Provision Experiments: An International

Comparison."

Jon D. Haveman, Janet S. Netz, and Vivian Lei

"International Integration and Growth: A Survey and Empirical Inwextigation."

Keith V. Smith, Nabil T, Kheury, and Peter L. MacKay

"Comparing Working Capiual Practices in Canada, the United States, und Autiralla: A Note."

John A. Carison and Newre T. Valev

"Expectations Formation and toflation Persistence."

John A. Carisen aad Carol L. Osier

"Determinants of Currency Risk Premiums."

Jon D. Haveman, Usha Nair-Reichert, and Jerry Thursby

"Trade Reduction, Diversion and Compression: Empirical Regularities in the Effect of Pratective Measures,"

Kale Krishma, Suddhasatwa Roy, and Marie Thursby

"Can Sabsidites for MARs be Procompetitive?"

Gabriele Caraers and Johannes Winkler

"Stores, Prices and Currency Substitution" 
No, 99-002 John A. Carisen and Neven T. Valev

"Sources of Dispersion in Inflation Forecasts"

No. 99-003 Timothy N. Cason, Tatsuyoshi Saijo and Takehiko Yamato

"Voluntary Participation and Spite in Public Good Provision Experiments: An International Cemparison"

No. 99-004 Jny Dahya, John J. MeConnell and Nickolaos G. Travlos

"The Cadbury Committee, Corporate Performance and Top Management Turnaver"

No. 99-0e5 David J. Denis, Diane K. Denir and Keven Yost

"Global Diversification, Industrial Diversification and Firm Value"

No. 99-006 Timothy B. Folta and Walter J. Ferrier

"The Effect of National Culture on Partner Buyouts in Cross-Border Biotechnology Alliances"

No. 99-007 Jen D. Haveanan and Jerry G. Thursby

-The Impact of Tariff and Non-Tariff Barriers to Trade in Agricultural Commodities:

A Disageregated Approach"

No. 99-008 Huseyin Gulen and Stewart Mayhew

"Steck Indes Futures Trading and Volatility in International Equily Markets"

Ne. 99-009 Stefan Lutz and Aleasandro Turrini

"Skills, Labour Costs and Vertically Differentiated Industries: A Geaeral Equilibrium Analysis"

No. 99-016 Michael Watts and Alezander Kovzik

"Reforming Undergraduate Economies Instruction in the Former Soviet Oaion" 